\title{
KONTRIBUSI KEMAMPUAN BERPIKIR KRITIS DAN KEMAMPUAN MEMORI TERHADAP PRESTASI BELAJAR IKATAN KIMIA PADA SISWA KELAS X SMAN 2 SUKOHARJO TAHUN AJARAN 2016/2017
}

\author{
Rismaya Winiasih, Ashadi*, dan Bakti Mulyani \\ Program Studi Pendidikan Kimia, FKIP, Universitas Sebelas Maret, Surakarta, Indonesia
}

`Keperluan korespondensi, telp : 0816671690,e-mail : ashadi_uns@yahoo.com

\begin{abstract}
ABSTRAK
Tujuan dari penelitian ini adalah untuk mengetahui : (1) Adanya korelasi antara kemampuan berpikir kritis dengan prestasi belajar siswa pada materi pokok Ikatan Kimia. (2) Adanya korelasi antara memori dengan prestasi belajar siswa pada materi pokok Ikatan Kimia. (3) Adanya korelasi antara kemampuan berpikir kritis dan memori bersama-sama dengan prestasi belajar siswa pada materi pokok Ikatan Kimia (4) Berapa besar kontribusi kemampuan berpikir kritis dan memori terhadap capaian prestasi belajar siswa. Penelitian ini menggunakan metode korelasional. Teknik pengumpulan data menggunakan metode tes untuk mengukur pengetahuan dan kemampuan berpikir kritis serta kemampuan memori. Uji hipotesis dilakukan menggunakan ANAVA dua jalan dengan bantuan aplikasi SPSS 18. Berdasarkan hasil penelitian disimpulkan bahwa: (1)Terdapat korelasi positif antara kemampuan memori dengan prestasi belajar siswa dengan indeks korelasi 0,673. (2) Terdapat korelasi positif antara kemampuan berpikir kritis dengan prestasi belajar siswa dengan indeks korelasi 0,481. (3) Terdapat korelasi positif antara kemampuan memori dan kemampuan berpikir kritis bersama sama terhadap prestasi belajar siswa dengan indeks korelasi 0,757. (4) Sumbangan efektif kemampuan memori dan berpikir kritis sebesar $40.27 \%$ dan $17.07 \%$. Sumbangan relatif kemampuan memori dan berpikir kitis sebesar $70.23 \%$ dan $29.76 \%$. Prestasi belajar dapat diprediksi melalui pesamaan regresi $Y=16,194+0,284 X 1+0,226 X 2$.
\end{abstract}

Kata Kunci : Kemampuan Memori, Kemampuan Berpikir Kritis, Prestasi Belajar, Ikatan Kimia

\section{PENDAHULUAN}

Materi Pelajaran Kimia di SMA banyak berisi konsep yang cukup sulit untuk dipahami siswa karena menyangkut reaksi-reaksi kimia dan perhitungan, serta menyangkut konsepkonsep yang bersifat abstrak dan dianggap oleh siswa merupakan materi yang relatif baru dan belum pernah diperolehnya ketika di SMP [1].

Penjelasan konsep-konsep kimia pada umumnya berlandaskan struktur materi dan ikatan kimia yang merupakan subyek yang tidak mudah untuk dipelajari. Konsep-konsep abstrak tersebut sangat penting dipelajari karena konsep-konsep kimia selanjutnya akan sulit dipahami, jika konsep sebelumnya tidak dikuasai dengan baik. Keabstrakan konsep-konsep kimia tersebut menjadikan kesulitan bagi siswa dan juga guru di dalam membelajarkan kimia [2].

Akibatnya siswa cenderung untuk membawa pandangan tersendiri tentang fenomena ilmiah dan pengalaman yang telah mereka miliki. Konsepsi unik tentang fenomena alam yang dimiliki siswa sering resisten terhadap pengajaran karena konsepsi ini telah tertanam kuat dalam pikiran siswa, terutama konsepsi yang diperoleh siswa dari pengalaman sehari-hari. Selain itu, sifat keabstrakan konsep-konsep kimia juga sejalan dengan konsep-konsep yang melibatkan perhitungan matematis. Hal ini menunjukkan bahwa pembelajaran kimia memerlukan 
seperangkat keterampilan berpikir tingkat tinggi dan salah satunya adalah kemampuan berpikir kritis. Berpikir kritis adalah proses merefleksi kembali dalam membentuk argument dan pernyataan [3]. Globalisasi menuntut sumber daya manusia yang berdaya saing tinggi, kompetitif. Disamping diperlukan untuk menghadapi masa depan sebenarnya juga diperlukan untuk memahami konsep-konsep yang dipelajari termasuk kimia.

Selain kemampuan berpikir kritis, kemampuan memori juga berpengaruh terhadap prestasi belajar siswa. Prestasi belajar di pengaruhi oleh dua faktor yaitu faktor internal (faktor dari dalam diri siswa) dan faktor eksternal (faktor dari luar diri siswa) [4]. Salah satu faktor internal yang mempengaruhi prestasi belajar siswa adalah kemampuan memori yang diperoleh dari pengalaman belajar atau pelajaran sebelumnya [5]

Setiap siswa memiliki kemampuan memori yang berbeda-beda sehingga dapat mempengaruhi daya tangkap dan daya terima bahan ajar yang berbeda pula. Kemampuan memori berkaitan dengan kemampuan memasukkan, menyimpan dan menimbulkan kembali hal-hal yang pernah di lihat, di dengar, dan di lakukan dalam proses pembelajaran. Seorang siswa yang memiliki kemampuan memori yang tinggi maka ia akan lebih cepat menangkap materi yang di sampaikan oleh guru dan segera menyimpannya kedalam memori jangka pendek yang selanjutnya akan di kirim ke memori jangka panjang.

Dari observasi awal telah diketahui bahwa nilai ulangan harian materi pokok ikatan kimiasiswa kelas $X$ di SMAN 2 Sukoharjo rata-rata belum tuntas. Sehingga seringkali masih perlu diadakan perbaikan.

Dari latar belakang diatas perlu dilakukan penelitian mengenai korelasi kemampuan berpikir kritis dan kemampuan memori terhadap prestasi belajar pada materi ikatan kimia kelas $X$ SMAN 2 Sukoharjo tahun ajaran 2016/2017.

\section{METODE PENELITIAN}

Metode yang digunakan dalam penelitian adalah korelasional. Terdapat dua variable bebas dan dua variable terikat. Untuk lebih jelasnya dapa dilihat dalam Tabel 1.

Tabel 1. Rancangan Penelitian

\begin{tabular}{llll}
\hline \multicolumn{1}{c}{$Y \mathbf{X}$} & $\mathbf{X}_{\mathbf{1}}$ & $\mathbf{X}_{\mathbf{2}}$ & $\mathbf{X}_{\mathbf{1}} \mathbf{X}_{\mathbf{2}}$ \\
\hline \multicolumn{1}{c}{$\mathbf{Y}_{\mathbf{1}} \quad \mathrm{X}_{1} \mathrm{Y}_{1}$} & $\mathrm{X}_{2} \mathrm{Y}$ & $\mathrm{X}_{1} \mathrm{X}_{2} \mathrm{Y}_{1}$ \\
\hline Keterangan : \\
$\mathrm{X}_{1}$ & : kemampuan bepikir kritis \\
$\mathrm{Y}_{1}$ & \multicolumn{2}{l}{ : kemampuan memori } \\
$\mathrm{X}_{1} \mathrm{Y}_{1}$ & : Korelasi kemampuan berpikir kritis \\
& terhadap prestasi belajar siswa \\
$\mathrm{X}_{2} \mathrm{Y}_{2}$ & : Korelasi kemampuan memori \\
& terhadap prestasi belajar siswa
\end{tabular}

Populasi dari penelitian ini adalah seluruh siswa kelas X SMA Negeri 2 Sukoharjo pada semester ganjil tahun ajaran 2016/2017 yang terdiri dari 4 kelas. Pengambilan sampel menggunakan teknik Cluster Random Sampling yaitu menetapkan dua kelas MIA semeseter genap secara acak. Dari ke delapan kelas X MIA SMA Negeri 2 Sukoharjo, diambil dua kelas secara acak untuk dijadikan kelas sampel dan diperoleh kelas X MIA 2 dan X MIA 3 . Variabel bebas dalam penelitian ini adalah kemampuan bepikir kritis dan kemampuan memori, variabel terikat dalam penelitian ini adalah prestasi belajar pada materi ikatan kimia.

Teknik pengumpulan data adalah dengan menggunakan instrumen tes untuk mengukur kemampuan berpikir kritis ,kemampuan memori, dan prestasi pengetahuan dengan bentuk soal objektif.

Teknik analisis instrumen pengetahuan menggunakan : (1) Uji validitas menggunakan formula Gregory dinyatakan valid, (2) Uji reliabilitas untuk hasil uji coba instrumen dengan bantuan SPSS 18 dinyatakan reliabel dengan harga reliabilitas 0,743 , (3) Uji tingkat kesukaran untuk hasil uji coba instrumen diperoleh hasil dari 25 soal yang diuji cobakan, 22 soal tergolong sukar, 2 soal tergolong sedang dan 1 soal tergolong mudah, (4) Uji daya beda soal untuk hasil uji coba instrumen diperoleh hasil dai 25 
soal, 16 soal dinyatakan valid dan 9 soal dinyatakan tidak valid karena daya bedanya dibawah 0,20.

Teknik analisis instrumen kemampuan berpikir kritis menggunakan : (1) Uji validitas menggunakan formula Gregory dinyatakan valid, (2) Uji reliabilitas dengan bantuan SPSS 18 dinyatakan reliabel dengan harga reliabilitas 0,738 .

Uji prasyarat analisis yang dilakukan adalah uji normalitas, dan uji homogenitas. Sedangkan teknik analisis data menggunakan uji analisis regesi ganda. Uji prasyarat analisis dan uji hipotesis dalam penelitian ini dilakukan dengan bantuan SPSS 18.

\section{HASIL DAN PEMBAHASAN}

\section{Uji Prasyarat Analisis}

\section{a. Uji Normalitas}

Data mengenai prestasi siswa, kemampuan memori, serta kemampuan berfikir kritis yang telah diperoleh melalui penelitian, diuji normalitasnya menggunakan uji Kolmogorov Smirnov. Ringkasan hasil uji normalitas disajikan dalam Tabel 2.

Tabel 2. Tabel Normalitas Semua Variabel

\begin{tabular}{clrl}
\hline No & Variabel & Sig. & Kesimpulan \\
\hline 1 & Prestasi & 0.200 & Normal \\
2 & Memori & 0.084 & Normal \\
3 & KBK & 0.001 & Tidak Normal \\
\hline
\end{tabular}

Terlihat dari tabel, variabel prestasi dan variabel kemampuan memori memiliki nilai signifikansi $>0,05$. Dengan demikian dapat dikatakan bahwa kedua variabel tersebut telah berdistribusi normal. Namun untuk variabel kemampuan berfikir kritis, nilai signifikansi lebih kecil dari 0,05 yang menunjukkan bahwa data variabel ini tidak berdistribusi normal.

\section{b. Uji Independensi}

Uji independensi disebut juga uji multikolinearitas. Multikolinearitas adalah keadaan dimana dua variabel saling independen. Adanya multikolinearitas menyebabkan pengaruh masing- masing variabel independen sulit dideteksi. Untuk menguji independensi dilakukan dengan dua cara, yaitu dengan melihat nilai VIF (Variance Inflation Factor) yang tertera pada hasil output analisis menggunakan SPSS 18, atau dengan menggunakan rumus korelasi Pearson. Ringkasan hasil uji independensi terangkum pada Tabel 3

Tabel 3. Tabel Multikolinearitas

\begin{tabular}{llll}
\hline No & Variabel & VIF & Kesimpulan \\
\hline 1 & Memori & 1.046 & $\begin{array}{l}\text { Tidak terjadi } \\
\text { multikolinearitas }\end{array}$ \\
2 & KBK & 1.046 & $\begin{array}{l}\text { Tidak terjadi } \\
\text { multikolinearitas }\end{array}$ \\
\hline
\end{tabular}

Dua variabel dinyatakan tidak terjadi multikolinearitas apabila $0,1<$ harga VIF < 10. Berdasarkan data, terlihat bahwa harga VIF berada di antara 0,1 dan 10 , sehingga dapat disimpulkan bahwa tidak terjadi multikolinearitas.

Selanjutnya, menggunakan cara yang kedua, ringkasan hasil uji independensi dengan rumus Karl Pearson terangkum dalam Tabel 4

Tabel 4.Tabel Uji Independensi

\begin{tabular}{llll}
\hline No & Variabel & & $\begin{array}{l}\text { Berpikir } \\
\text { Kritis }\end{array}$ \\
\hline 1 & Memori & Korelasi sig. & 0.088 \\
\hline
\end{tabular}

Hasil uji dikatakan independen apabila nilai signifikansi lebih besar dari 0,05 yaitu 0,088 . Dari tabel dapat dilihat bahwa hubungan antara variabel kemampuan memori dan kemampuan berfikir kritis memiliki nilai signifikansi yang lebih besar dari 0,05, sehingga dapat disimpulkan bahwa kedua variabel saling independen, tidak ada hubungan antara kedua variabel tersebut.

\section{c. Uji Heterokedastisitas}

Heterokedastisitas

keadaan dimana terjadinya
ketidaksamaan varian dari residual pada model regresi. Model regresi yang baik mensyaratkan tidak adanya masalah 
heterokedastisitas karena akan menyebabkan estimator tidak efisien dan nilai koefisien determinasi menjadi sangat tinggi. Untuk mendeteksi ada tidaknya heterokedastisitas adalah dengan melihat pola titik-titik pada gambar berikut. Jika titik- titik menyebar dengan pola yang tidak jelas di atas dan di bawah angka 0 pada sumbu $Y$, maka tidak terjadi masalah heterokedastisitas.

Selain dengan metode grafik, uji ini juga dapat dilakukan dengan Uji Glejser. Hasil uji ini terangkum dalam Tabel 5.

Tabel 5. Tabel Uji Heterogenitas

\begin{tabular}{|c|c|c|c|c|c|}
\hline \multirow[t]{3}{*}{ Model } & \multirow{2}{*}{\multicolumn{2}{|c|}{$\begin{array}{l}\text { Unstandardized } \\
\text { Coefficients }\end{array}$}} & \multirow{3}{*}{$\begin{array}{l}\text { Standardized } \\
\text { Coefficients } \\
\text { Beta }\end{array}$} & \multirow[t]{3}{*}{$\mathrm{T}$} & \multirow[t]{3}{*}{ Sig- } \\
\hline & & & & & \\
\hline & $\mathrm{B}$ & Std_Error & & & \\
\hline (Constant) & 6.916 & 1.681 & & 4.114 & .000 \\
\hline 1 Memori & -.041 & .023 & -.225 & -1.800 & .077 \\
\hline $\mathrm{KBK}$ & .013 & .031 & .053 & .425 & .672 \\
\hline
\end{tabular}

Data dikatakan tidak memiliki masalah heterokedastisitas apabila nilai signifikansi variabel independen lebih besar dari 0,05. Dari data terlihat bahwa nilai signifikansi variabel kemampuan memori dan variabel kemampuan berfikir kritis lebih besar dari 0,05 sehingga dapat disimpulkan tidak terdapat masalah heterokedastisitas.

\section{d. Uji Linearitas Regresi}

Uji asumsi selanjutnya untuk regresi linear berganda adalah uji linearitas. Uji linearitas dilakukan antara kemampuan memori dengan prestasi, kemampuan berpikir kritis dengan prestasi.

1) Uji Linearitas Kemampuan Memori (X1) terhadap Prestasi Belajar Siswa (Y)

Uji linearitas pertama adalah antara kemampuan memori dan prestasi belajar siswa. Rangkuman hasil uji linearitas menggunakan SPSS disajikan dalam Tabel 6.

Tabel 6. Uji Linearitas Kemampuan Memori (X1) terhadap Prestasi Belajar Siswa (Y)

\begin{tabular}{|c|c|c|c|c|c|c|c|}
\hline & & & $\begin{array}{l}\text { Sum of } \\
\text { Squares }\end{array}$ & df & $\begin{array}{l}\text { Mean } \\
\text { Square }\end{array}$ & F & Sig. \\
\hline \multicolumn{2}{|c|}{ Kognitif * } & (Combined) & 3991.294 & 18 & 221.739 & 3.743 & .000 \\
\hline \multirow[t]{4}{*}{ Memori } & Between & Linearity & 3096.011 & 1 & 3096.011 & 52.266 & .000 \\
\hline & Groups & $\begin{array}{l}\text { Deviation } \\
\text { from Linearity }\end{array}$ & 895282 & 17 & 52.664 & .889 & .589 \\
\hline & \multicolumn{2}{|c|}{ Within Groups } & 2843.333 & 48 & 59.236 & & \\
\hline & \multicolumn{2}{|l|}{ Total } & 6834.627 & 66 & & & \\
\hline
\end{tabular}

bahwa nilai signifikansi pada penyimpangan dari linearitas (Deviation from Linearity) adalah 0,589, lebih besar dibanding 0,05 sehingga dapat disimpulkan bahwa model regresi antara kemampuan memori dan prestasi belajar bersifat linear.
2) Uji Linearitas Kemampuan Berfikir Kritis (X2) terhadap Prestasi Belajar Siswa (Y)

Rangkuman hasil uji linearitas antara kemampuan berfikir kritis dan prestasi belajar siswa terangkum dalam Tabel 7 
Tabel 7. Uji Linearitas Kemampuan Berfikir Kritis (X2) terhadap Prestasi Belajar Siswa (Y)

\begin{tabular}{llllllll}
\hline & & \multicolumn{2}{l}{$\begin{array}{l}\text { Sum of df } \\
\text { Squares }\end{array}$} & $\begin{array}{l}\text { Mean } \\
\text { Square }\end{array}$ & F & Sig. \\
\hline Kognitif * & & (Combined) & 2090.227 & 7 & 298.604 & 3.713 & .002 \\
KBK & Between & Linearity & 1580.191 & 1 & 1580.191 & 19.651 & .000 \\
& Groups & Deviation & 510.036 & 6 & 85.006 & 1.057 & .399 \\
& & & & & & \\
& & from Linearity & & & & & \\
\multicolumn{2}{l}{ Within Groups } & 4744.400 & 59 & 80.414 & & \\
\multicolumn{2}{l}{ Total } & 6834.627 & 66 & & & \\
\hline
\end{tabular}

Berdasarkan tabel, dapat dilihat bahwa nilai signifikansi pada penyimpangan dari linearitas (Deviation from Linearity) adalah 0,399, lebih besar dibanding 0,05 sehingga dapat disimpulkan bahwa model regresi antara kemampuan memori dan prestasi belajar bersifat linear.

\section{Pengujian Hipotesis}

Setelah uji asumsi dalam regresi linear berganda terpenuhi, maka dilakukan uji korelasi baik secara serentak maupun secara sendiri-sendiri untuk mengetahui ada tidaknya pengaruh korelasi positif yang signifikan antara variabel-variabel bebas dengan variabel terikat. Selanjutnya dilakukan uji regresi linear berganda untuk mendapatkan persamaan regresi antara variabel-variabel bebas dengan variabel terikat.

\section{a. Uji Hipotesis Pertama}

Uji regresi linear dapat dilakukan bila terbukti ada korelasi antara variabel bebas dengan variabel terikatnya. Hipotesis pertama menyatakan bahwa ada korelasi positif yang signifikan antara kemampuan memori dengan prestasi belajar siswa. Dengan ketentuan:

$\mathrm{HO}$ : Tidak ada hubungan yang signifikan antara kemampuan memori dengan prestasi belajar siswa.

$\mathrm{H} 1$ : Ada hubungan yang signifikan antara kemampuan memori dengan prestasi belajar siswa.
Tabel 8. Tabel Uji Hipotesis Pertama

Correlations

\begin{tabular}{llll}
\hline & Memori & Kognitif \\
\hline Memori & Sig. (2-tailed) & & $.673^{* *}$ \\
N & 67 & 67 \\
\hline Pearson Correlation & $.673^{* *}$ & 1 \\
Kognitif Sig. (2-tailed) & .000 & \\
N & 67 & 67 \\
\hline * Correlation is significant at the 0.01 level (2-tailed).
\end{tabular}

Dari Tabel 8 terlihat bahwa hasil signifikansi uji t-dua pihak antara kemampuan memori dengan prestasi belajar siswa adalah 0,000 sangat jauh dari 0,05. Karena signifikansi $<0,050$ maka $\mathrm{H} 0$ ditolak dan $\mathrm{H} 1$ diterima, sehingga disimpulkan bahwa ada hubungan yang signifikan antara kemampuan memori dengan prestasi belajar siswa,

Koefisien korelasi antara kemampuan memori dengan prestasi adalah 0,673 yang berarti bahwa terdapat korelasi positif yang cukup kuat antara kemampuan memori dengan prestasi belajar siswa. Dengan demikian dari uji hipotesis pertama disimpulkan bahwa ada korelasi positif yang signifikan antara kemampuan memori dengan prestasi belajar siswa.

\section{b. Uji Hipotesis Kedua}

Hipotesis kedua menyatakan bahwa ada korelasi positif yang signifikan antara kemampuan berfikir kritis dengan prestasi belajar siswa. Dengan ketentuan, 
$\mathrm{HO}$ : Tidak ada hubungan yang signifikan antara kemampuan berfikir kritis dengan prestasi belajar siswa.

$\mathrm{H} 1$ : Ada hubungan yang signifikan antara kemampuan berfikir kritis dengan prestasi belajar siswa.

Tabel 9. Tabel Uji Hipotesis Kedua

Correlations

\begin{tabular}{llll}
\hline & & Kognitif & KBK \\
\hline \multirow{3}{*}{ Kognitif } & Pearson Correlation & 1 & $.481^{* *}$ \\
& Sig. (2-tailed) & & .000 \\
N & 67 & 67 \\
KBK & Pearson Correlation & $.481^{* *}$ & 1 \\
& Sig. (2-tailed) & .000 & \\
N*. Correlation is significant at the 0.01 level (2-tailed).
\end{tabular}

Dari Tabel 9 terlihat bahwa hasil signifikansi uji t-dua pihak antara kemampuan memori dengan prestasi belajar siswa adalah 0,000 dan $\mathrm{H} 1$ diterima. Karena signifikansi $<0,050$ maka $\mathrm{HO}$ ditolak, sehingga disimpulkan bahwa ada hubungan yang signifikan antara kemampuan berfikir kritis dengan prestasi belajar siswa.

Koefisien korelasi antara kemampuan memori dengan prestasi adalah 0,481 yang berarti bahwa terdapat korelasi positif yang cukup kuat antara kemampuan memori dengan prestasi belajar siswa. Dengan demikian dari uji hipotesis pertama disimpulkan bahwa ada korelasi positif yang signifikan antara kemampuan memori dengan prestasi belajar siswa.

\section{c. Uji Hipotesis Ketiga}

Hipotesis ketiga menyatakan bahwa ada korelasi positif yang signifikan antara kemampuan memori dan kemampuan berpikir kritis dengan prestasi belajar siswa. Dengan,

$\mathrm{HO}$ : Tidak ada hubungan yang signifikan antara kemampuan memori dan kemampuan berfikir kritis dengan prestasi belajar siswa.

$\mathrm{H} 1$ : Ada hubungan yang signifikan antara kemampuan memori dan kemampuan berfikir kritis dengan prestasi belajar siswa.

Tabel 10. Tabel Uji Hipotesis Ketiga

\begin{tabular}{|c|c|c|c|c|c|c|}
\hline \multicolumn{7}{|c|}{ ANOVA $^{a}$} \\
\hline & $\overline{\mathrm{del}}$ & Sum of Squares & df & Mean Square & $\mathrm{F}$ & Sig. \\
\hline \multirow{3}{*}{1} & Regression & 3919.705 & 2 & 1959.853 & 43.031 & $.000^{\mathrm{b}}$ \\
\hline & Residual & 2914.921 & 64 & 45.546 & & \\
\hline & Total & 6834.627 & 66 & & & \\
\hline
\end{tabular}

Dari Tabel 10 dapat dilihat bahwa nilai $F$ hitung $(43,031)>F$ tabel $(3,14)$ sehingga disimpulkan bahwa kemampuan memori dan kemampuan berfikir kritis secara bersama-sama berpengaruh terhadap prestasi belajar siswa. Kemudian untuk mengetahui signifikan atau tidaknya dapat dilihat dari nilai signifikansinya. Karena nilai signifikansi $0,000<0,050$, maka $\mathrm{HO}$ ditolak, sehingga disimpulkan bahwa ada hubungan yang signifikan antara kemampuan memori, dan kemampuan berpikir kritis secara bersama-sama berpengaruh terhadap prestasi belajar siswa.

Untuk mengetahui apakah korelasinya positif atau negatif dapat dilihat pada koefisien regresinya untuk setiap variabel bebas yang bisa dilihat pada tabel 11 berikut. 
Tabel 11. Tabel Korelasi Regresi

Coefficients $^{\mathrm{a}}$

\begin{tabular}{|c|c|c|c|c|c|c|c|}
\hline \multirow[t]{2}{*}{ Model } & \multicolumn{2}{|c|}{$\begin{array}{l}\text { Unstandardized } \\
\text { Coefficients }\end{array}$} & \multirow{2}{*}{$\begin{array}{l}\text { Standardized } \\
\text { Coefficients } \\
\text { Beta }\end{array}$} & \multirow[t]{2}{*}{$\mathrm{t}$} & \multirow[t]{2}{*}{ Sig. } & \multicolumn{2}{|c|}{$\begin{array}{l}\text { Collinearity } \\
\text { Statistics }\end{array}$} \\
\hline & $\mathrm{B}$ & Std. Error & & & & Tolerance & VIF \\
\hline (Constant) & 16.194 & 2.901 & & 5.581 & .000 & & \\
\hline Memori & .284 & .040 & .598 & 7.167 & .000 & .956 & 1.046 \\
\hline KBK & .226 & .053 & .355 & 4.253 & .000 & .956 & 1.046 \\
\hline
\end{tabular}

Dari Tabel 11 tersebut nilai $b$ atau koefisien regresi dari kemampuan memori dan kemampuan berfikir kritis siswa semuanya bernilai positif, sehingga dapatdisimpulkan bahwa ketiga variabel tersebut memiliki korelasi yang positif terhadap prestasi belajar siswa.

Untuk mengetahui keeratan hubungannya dapat dilihat dari nilai koefisien korelasi ganda, dari hasil SPSS 18 diperoleh nilai koefisien korelasinya 0,757 , sehingga disimpulkan korelasinya cukup kuat dan koefisien korelasi berganda yang bernilai positif juga menunjukkan bahwa korelasi antara kemampuan memori, kemampuan berpikir kritis siswa bersifat positif. Dengan demikian dari uji hipotesis ketiga disimpulkan bahwa ada korelasi positif yang signifikan antara kemampuan memori dan kemampuan berfikir kritis dengan prestasi belajar siswa.

Secara garis besar perlakuan analisa yang dilakukan pada penelitian ini meliputi beberapa tahap yaitu:

- Uji asumsi seperti uji normalitas, multikolinearitas, heterokedastisitas dan linearitas. Uji ini dilakukan dengan SPSS 18.

- Uji korelasi untuk mengetahui hubungan antara variabel-variabel bebas dengan variabel terikat. Uji ini dilakukan dengan SPSS 18.

- Uji regresi linear berganda untuk mengetahui hubungan variabelvariabel bebas dengan terikat secara serentak dan mengetahui persamaan regresinya. Uji ini dilakukan dengan SPSS 18.

Uji asumsi yang pada regresi linear berganda yaitu uji normalitas dilakukan dengan uji Kolmogorov-Smirnov, uji multikolinearitas dilakukan dengan melihat nilai VIF (Variance Inflation Factor) yang ada pada tiap variabel bebas, kemudian uji heterokedastisitas dilakukan dengan metode grafik dan perhitungan dengan uji Glejser, dan linearitas dilakukan dengan uji linearitas yang ada pada menu SPSS 18. Analisis korelasi yang digunakan adalah analisis korelasi bivariat yang akan menyelidiki hubungan antara dua variabel yaitu kuat atau tidaknya hubungan, arah hubungan dan berarti atau tidaknya hubungan. Korelasi yang digunakan adalah korelasi Pearson, karena korelasi ini mengukur hubungan secara linear pada skala interval.

Tabel 12. Hasil Uji Koefisien dan Keberartian Model Regresi Linear

\begin{tabular}{cccccc}
\hline \multirow{2}{*}{ Model } & \multicolumn{2}{c}{$\begin{array}{c}\text { Unstandardized } \\
\text { Coefficients }\end{array}$} & $\begin{array}{c}\text { Standardized } \\
\text { Coefficients }\end{array}$ & \multirow{2}{*}{ t } & Sig. \\
\cline { 2 - 4 } & $\mathrm{B}$ & Std. Error & Beta & & \\
\hline (Constant) & 16.194 & 2.901 & & 5.581 & .000 \\
Memori & .284 & .040 & .598 & 7.167 & .000 \\
KBK & .226 & .053 & .355 & 4.253 & .000 \\
\hline
\end{tabular}


Dari Tabel 12 nilai B merupakan koefisien-koefisien yang ada pada model regresi, sedangkan nilai $t$ atau signifikansi dapat digunakan untuk menentukan apakah koefisien regresi tersebut signifikan atau tidak. Dari tabel dapat diketahui bahwa model yang didapatkan yaitu:

$$
Y=16,194+0,284 X 1+0,226 X 2
$$

Untuk mengetahui koefisien regresi dari masing-masing variabel signifikan atau tidak, cukup dilihat nilai signifikansi bila nilai signifikansi $<0,05$, maka dapat disimpulkan bahwa koefisien regresi signifikan. Dari Tabel 4.15 dapat dilihat bahwa nilai signifikansi pada Kemampuan memori dan Berpikir kritis siswa semuanya $<0.05$, sehingga disimpulkan bahwa seluruh koefisien regresi yang didapat signifikan. Persamaan regresi tersebut berarti

- Konstanta b0 = 16,194 artinya jika kemampuan memori dan berpikir kritis siswa nilainya 0 , maka prestasi siswa nilainya positif sebesar 16,194.

- Konstanta b1 =0,284 artinya jika berpikir kritis siswa nilainya tetap, sedangkan kemampuan memori nilainya ditingkatkan 1 maka prestasi siswa akan meningkat sebesar 0,284.

- Konstanta b2 =0,226 artinya jika kemampuan memori siswa nilainya tetap, sedangkan berpikir kritis nilainya ditingkatkan 1 maka prestasi siswa akan meningkat sebesar 0,226.

Bila persamaan regresi telah diperoleh, maka sumbangan efektif dan sumbangan relatif dari masing-masing variabel dapat dihitung.

Tabel 13. Sumbangan Efektif dan Sumbangan Relatif Variabelvariabel Bebas terhadap Prestasi Belajar Siswa

\begin{tabular}{lcc}
\hline Variabel & $\begin{array}{c}\text { Sumbangan } \\
\text { Realtif }\end{array}$ & $\begin{array}{c}\text { Sumbangan } \\
\text { Efektif }\end{array}$ \\
\hline Memori & $60.79 \%$ & $34.90 \%$ \\
KBK & $39.21 \%$ & $22.50 \%$ \\
\hline Jumlah & $100 \%$ & $57.40 \%$ \\
\hline
\end{tabular}

Rangkuman sumbangan setiap variabel dapat dilihat pada Tabel 13. Dari
Tabel 4.16 dapat diinterpretasikan bahwa kontribusi kemampuan memori dan berpikir kritis siswa terhadap prestasi belajar siswa adalah 57,4 \% sedangkan sisanya $42,6 \%$ dipengaruhi variabel lain yang tidak diteliti. Kemudian dapat dilihat bahwa sumbangan efektif maupun relatif dari kemampuan memori > berpikir kritis. Sumbangan efektif merupakan sumbangan variabel yang diteliti dilihat dari keseluruhan variabel termasuk yang tidak diteliti. Sumbangan efektif. Kemampuan memori yaitu $34.90 \%$ dan berpikir kritis $22.50 \%$. Kemampuan memori paling berkontribusi dibandingkan dengan berpikir kritis dengan nilai sumbangan relatif $60.79 \%$. Hal ini terjadi karena prestasi yang diteliti adalah prestasi siswa pada materi lkatan kimia kelas $X$ yang membutuhkan kemampuan menghafal (memori), sehingga kemampuan memori paling berpengaruh dibandingkan variabel yang lain. Sedangkan berpikir kritis hanya berkontribusi sebesar 39.21\%. Berdasarkan besarnya sumbangan efektif nampak bahwa variabel kemampuan memori memiliki sumbangann yang lebih dominan terhadap prestasi belajar Ikatan Kimia dibandingkan variabel minat belajar.

Hasil analisis menunjukkan bahwa memori dan kemampuan berpikir kritis mempunyai pengaruh terhadap hasil belajar siswa dalam materi Ikatan Kimia di kelas X SMAN 2 Sukoharjo. Disini kemampuan memori dan kemampuan berpikir kritis mempengaruhi hasil belajar siswa dalam mata pelajaran kimia, ini diambil dari pernyataan yang ada di teori bahwa hasil belajar merupakan tingkat kemampuan yang telah diajarkan mencakup tiga kemampuan sebagaimana yang telah diungkapkan oleh Bloom [6] bahwa tingkat kemampuan atau penugasan yang dapat dikuasai oleh siswa mencakup tiga aspek yaitu salah satunya adalah kemampuan kognitif (kognitif domain) yaitu kawasan yang berkaitan dengan aspek-aspek intelektual atau secara logis yang biasa diukur dari pikiran atau nalar. Kawasan ini terdiri dari 1) pengetahuan (knowledge) mencakup ingatan akan halhal yang pernah dipelajari dan disimpan 
dalam ingatan. 2) pemahaman (comprehension), mengacu pada kemampuan memahami makna materi. 3) penerapan (aplication), 4) analisis (analysis), 5) sintesis (synthesis), 6) evaluasi (evaluation). Nah, peneliti menggaris bawahi point pertama dan kedua. Pertama yaitu penengetahuan mencakup ingatan dan point kedua adalah pemahaman, mengacu pada kemampuan memahami makna materi atau dengan kata lain proses berpikir dan salah satu proses berpikir yaitu berpikir kritis meliputi: analisis, sintesis, pengenalalan masalah dan pemecahannya, kesimpulan, dan penilaian.

\section{KESIMPULAN}

1. Terdapat korelasi antara kemampuan memori dengan prestasi belajar siswa dengan indeks korelasi 0,673, bentuk korelasi positif, semakin tinggi kemampuan memori maka prestasi belajar siswa cenderung semakin tinggi.

2. Terdapat korelasi antara kemampuan berpikir kritis dengan prestasi belajar siswa dengan indeks korelasi 0,481, bentuk korelasi positif, semakin tinggi kemampuan berpikir kritis maka prestasi belajar siswa cenderung semakin tinggi.

3. Terdapat korelasi antara kemampuan memori dan kemampuan berpikir kritis bersama sama terhadap prestasi belajar siswa dengan indeks korelasi 0,757 , bentuk korelasi positif, semakin tinggi kemampuan memori dan kemampuan berpikir kritis maka prestasi belajar siswa cenderung semakin tinggi.

4. Sumbangan kemampuan memori dan kemampuan berpikir kritis terhadap prestasi belajar siswa. Sumbangan efektif kemampuan memori dan berpikir kritis sebesar $40.27 \%$ dan $17.07 \%$. Sumbangan relatif kemampuan memori dan berpikir kitis sebesar $70.23 \%$ dan $29.76 \%$. Prestasi belajar siswa tersebut dapat diprediksi dari kemampuan memori dan kemampuan berpikir kritis melalui regresi $Y=16,194+0,284 X 1+0,226$ $\mathrm{X} 2$.

\section{UCAPAN TERIMAKASIH}

Ibu Dra. Ari Dwi Listyani, M.Pd, selaku Kepala Sekolah SMA Negeri 2 Sukoharjo yang telah memberikan ijin penelitian dan Ibu Sri Matini R, S.Pd. selaku guru mata pelajaran kimia yang telah mengijinkan penulis menggunakan kelas untuk penelitan.

\section{DAFTAR RUJUKAN}

[1] Sunyono. (2009)Pembelajara IPA dengan Keterampilan Generik Sains [Online]. Tersedia blog.unila.ac.id/sunyono/files/06/ket erapilan-generik.pdf(Diakses tanggal 5 September 2016)

[2] Chandrasegaran, A.L., Treagust, D.F., \& Mocerino, M. (2008). An Evaluation of a Teaching Intervention to Promote Student's Ability to Use Multiple Level of Representation When Describing and Explaining Chemical Reactions. Res. Sci. Educ., 38 (2), 237-248.

[3] Ahmadi, A. \& Supriyono, W. (2008). Psikologi Belajar. Jakarta: Rineka Cipta.

[4] Kelly, S.E. (2001). Thinking Well: An Introduction to Critical Thinking. Texas : Mayfield Publishing Company.

[5] Daro'aeni, F., Yamtinah, S., \& Nurhayati, N. D. (2013). Pengaruh Kemampuan Memahami Bacaan, Kemampuan Memori, Dan Kemampuan Analisis Terhadap Belajar Siswa Pada Materi Pokok Koloid Kelas Xi Semester Genap Sma Negeri 1 Ngemplak Tahun Pelajaran 2012 / 2013, 2(3), 139145.

[6] Sudjana. (2007). Teknik Analisis Regresi dan Korelasi. Bandung:Tarsito. 